\title{
Structural Design Adapt to Building Mass Forms on Contoured Land At Warung Salse
}

\author{
Theresia Pynkyawati ${ }^{1}$, Rini Cahyani ${ }^{2}$ \\ ${ }^{I}$ Department of Architecture/ faculty of civil engineering and planning \\ ${ }^{2}$ Department of Architecture/ faculty of civil engineering and planning \\ thres@itenas.ac.id
}

\begin{abstract}
Warung Salse is located in Dago Giri Bandung; West Java is a public building built on the contoured ground. The criteria for the material used are light material, do not increase the soil's carrying capacity, and do not cause subsidence. The structure of Warung Salse adjusts to the shape of the building mass and the conditions of the ground contour so that the roof has a multifunctional role as a roof and wall covering with a sloping portal structure, seen from its shape that reaches the ground in front and shrinks behind following the view of the Warung Salse area. The research was conducted using the descriptive analysis method, discussing mass structure associated with mass order theory, mass form, roof structures, columns, beams, and structures on contoured soil. From the final result, the shape of the building mass and the structural model of the contoured soil will be known.
\end{abstract}

(C) 2021 IJBESR. All rights reserved.

Keywords: Warung Salse, Structural Design, Mass Forms, Contoured Land.

\section{Introduction}

The land is an essential factor in meeting the necessities of life used as a base for human habitation. The land is an area of the earth's surface that has certain characteristics that may be stable or cyclical either above or below this area, including the atmosphere, soil, geology, hydrology, plant and animal populations, and is influenced by human activities (economic, social, culture) in the past and present, then affect the potential use in the future [1]. In principle, there are two types of land, namely contoured land, and flat land. A contoured land is a land that has an unequal difference in height, while a flat land is a land that has an equal height or does not have a height difference.

Contouring land management must be considered, such as adjusting the building to the contour of the land, checking soil density, using land cultivation methods, and structurally and construction-strong materials. The arrangement of the mass in contoured land conditions affects several aspects, including the division of space, access and circulation paths, the shape of the mass and roof, and structures to building construction. In supporting the mass arrangement in contoured land, a suitable structural model is needed to minimize damage to the topography of the soil while optimizing the potential of the existing land. Structural models used on contoured land include terracing to maintain contour stability and minimize slope levels.

Warung Salse is a building with a structural model to form a mass. The shape of the building mass has a unique relationship between structure and architecture, such as the shape of the roof reaching the ground. The structural 
model used does not use heavy structural materials so that it supports the mass formation model of buildings standing on contoured land with a steep slope of up to 40 degrees.

\section{Material and Methods}

The research was conducted using a descriptive analysis method that discusses the typical structures that adapt to the shape of the building mass associated with mass structure theory, mass form, roof structure, columns, beams, and structures on contoured land.

\subsection{Model of Mass Formation and Order}

The building mass forming model is divided into four types. They are: forming a building mass with a cylindrical roof with four evenly supported points, forming a building mass with a translational roof with four uneven support points, forming a parabolic and saddle building mass with 2 or 4 uneven support points [2].

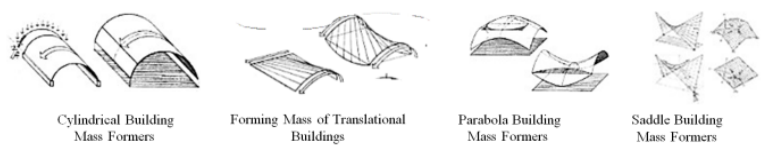

Source: (Ching, D.k, 2007)

Figure 1: Model and Form of Mass Order

The arrangement of the mass of the building is classified into 2, namely the outer space with no explicit flow and clear flow [2]. In selecting the mass order pattern, it is also necessary to pay attention to the pattern elements and composition of the mass order elements, such as position, orientation, and visual inertia.

Table 1: Pattern and composition of the Mass Order Element

\begin{tabular}{|l|l|l|}
\hline \multirow{2}{*}{ No. } & \multicolumn{2}{|c|}{ Pattern and Element Composition of Mass Order } \\
\cline { 2 - 3 } & Picture & \multicolumn{1}{|c|}{ Information } \\
\hline 1. & POSITION & $\bullet \begin{array}{l}\text { Determine the } \\
\text { position relative to its } \\
\text { environment. }\end{array}$ \\
\hline
\end{tabular}

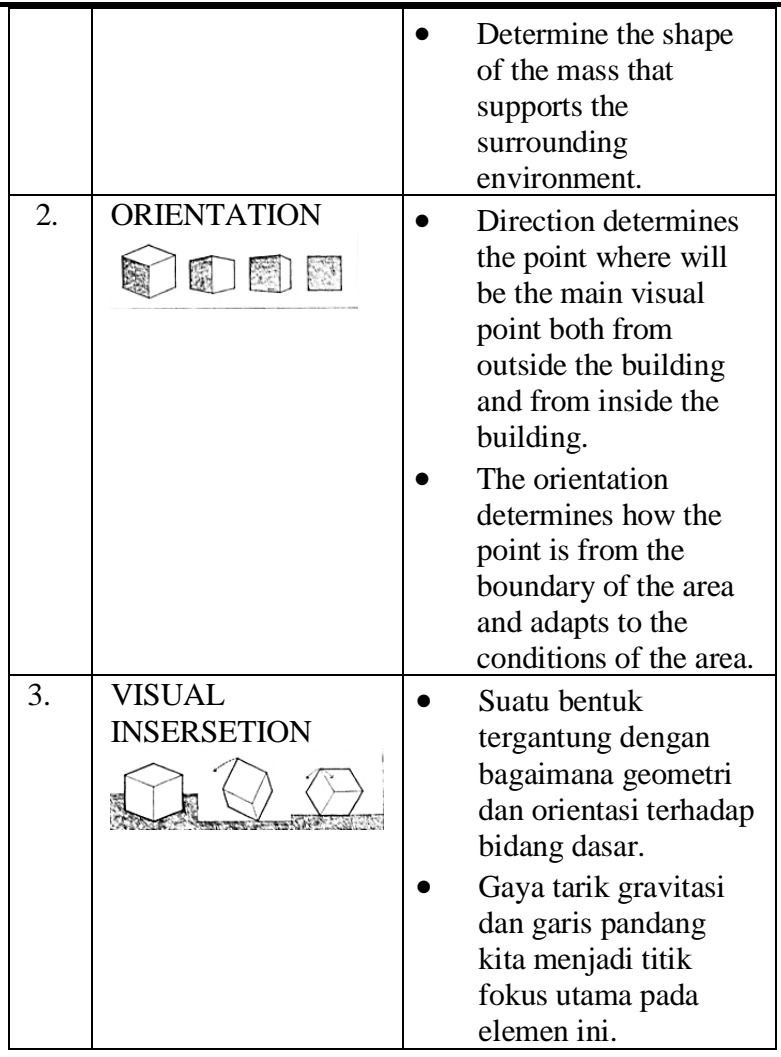

Source: (Ching, D.k, 2007)

\subsection{Types of Mass Processing on Countoired soils}

Processing of contour land is divided into three systems: the cut and fill method, the swale system, and the split level system [3]. The following is an explanation of the three types of systems:

[1]Cut and Fill System

Cut and Fill is a mountain slope flattened by the patio system by digging the back and filling the front. This system is equipped with a support wall.

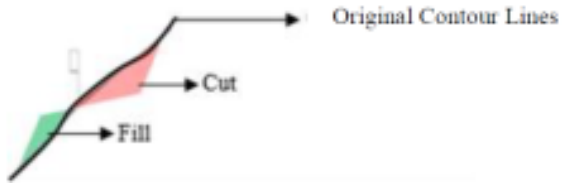

Source: (Frick, Heinz, 2003)

Figure 2: Cut and fill system 
[2]Split Level System

Split Level is a land with a gentle slope, allowing the building to have two floors, namely the bottom and top of the slope, with a half-level height difference on the slope $<10 \%$ $(<6$ degrees).

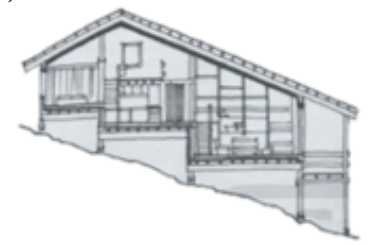

Source: (Frick, Heinz, 2003)

Figure 3: Cut and fill system

\section{[3]Swale system}

The swale system is a land slope where the mass composition adjusts the contour lines with a height difference always one level of the house. Swale houses stand-alone, in rows, etc., on slopes of $>10 \%$ to $20 \%$.

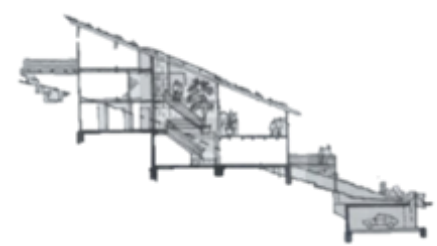

Source: (Frick, Heinz, 2003)

Figure 4: Cut and fill system

\subsection{Structure Retaining Wall}

There are nine retaining wall types: gravity type, cantilever type, counterfort type, pile type, gabion type, concrete block type, diagram type, solder pile type, and resentment [4]. Gabiontype soil retaining wall construction is a collection of blocks made of woven galvanized metal wire filled with coarse aggregate in the form of pebbles arranged vertically up with steps resembling terraces/steps.

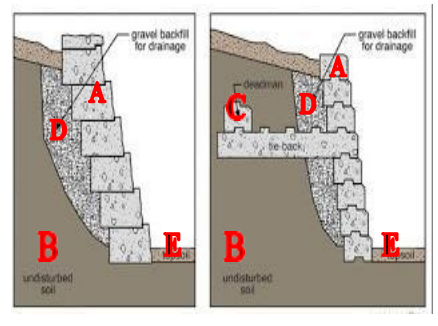

Where :

A: Bronjong

B: Undisturbed soil

C: Deachman

D: Gravel backfill for drainage

E: Topsol

Source: (Hardiyatmo, 2014)

Figure 5: Retaining Wall

\subsection{Structure Beam, Column and Floor Plate}

The central column is the column whose function is to refute the main load above it, while the practical column is the column that serves to help the main column as a wall binder so that the wall is stable. Beams are divided into several types: wooden beams, steel beams, and concrete beams [5] - double-duty floor plates, which must receive and distribute the burden and divide the space.
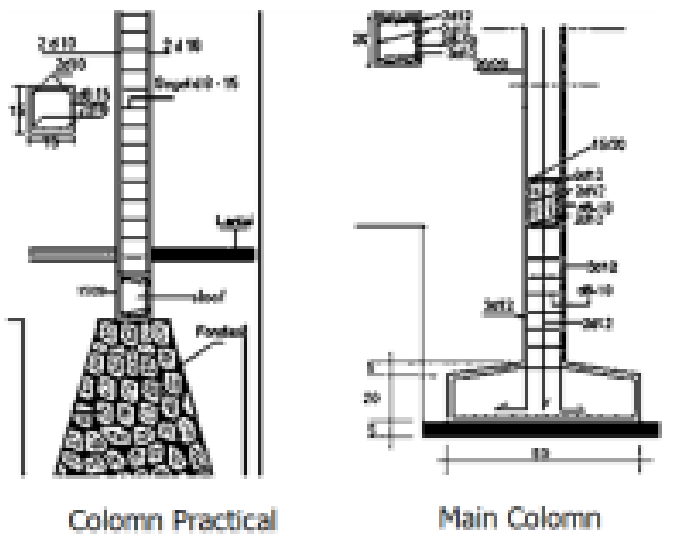

Source: (Heinz Frick, 2003)

Figure 6: Coloumn 


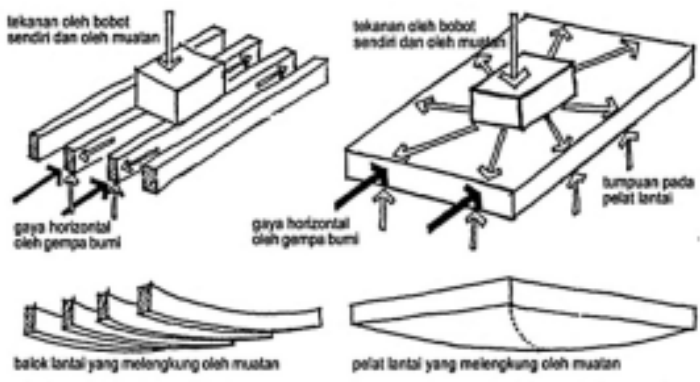

Source: (Heinz Frick, 2003)

Figure 7: Beam and Floor Plate

\subsection{Construction Roof}

The roof structure is a part or element of a structural system found on the top of a building. The design of the roof can be divided into two major parts, namely a flat roof and a sloping roof. The sloping roof functions as a successor to rainwater; therefore, the roof's slope depends on the type of roof covering used. Zinc and other sheet roof coverings can be used with a low slope because there is no fear of water overflow. One type of sloping roof is a gable, and the main structure of the sloping roof is the sloping portal beam structure. It has a tilted portal beam structure that forms the slope of the roof. It is one unit with the main column. The horses that support the portal beam structure are flat truss horses. A flat truss is the arrangement of linear elements (rods) that form triangles or triangular combinations to form a stable frame [5].
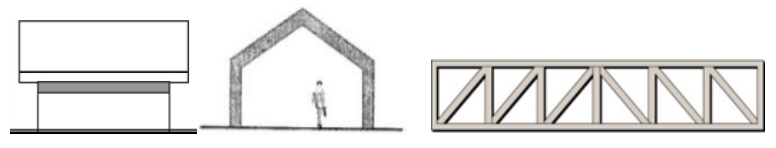

Source: (Cholis Noor Idham )

Figure 8: Shape and Construction Model Roof

\subsection{Material Roof}

The selection of roof covering material can be seen from the condition of the land and the slope of the roof so that it can be seen from the advantages and disadvantages of the type of roofing material. Strengths can be seen from the strength of the roof, the durability of the roof material, maintenance, and ease of installation. In contrast, the shortcomings can be seen from matching the roof material to the land conditions and the slope of the roof. The types of roofing materials are divided into 13, which can be seen in table 2 [8].

Table 2: Types of Roofing Materials

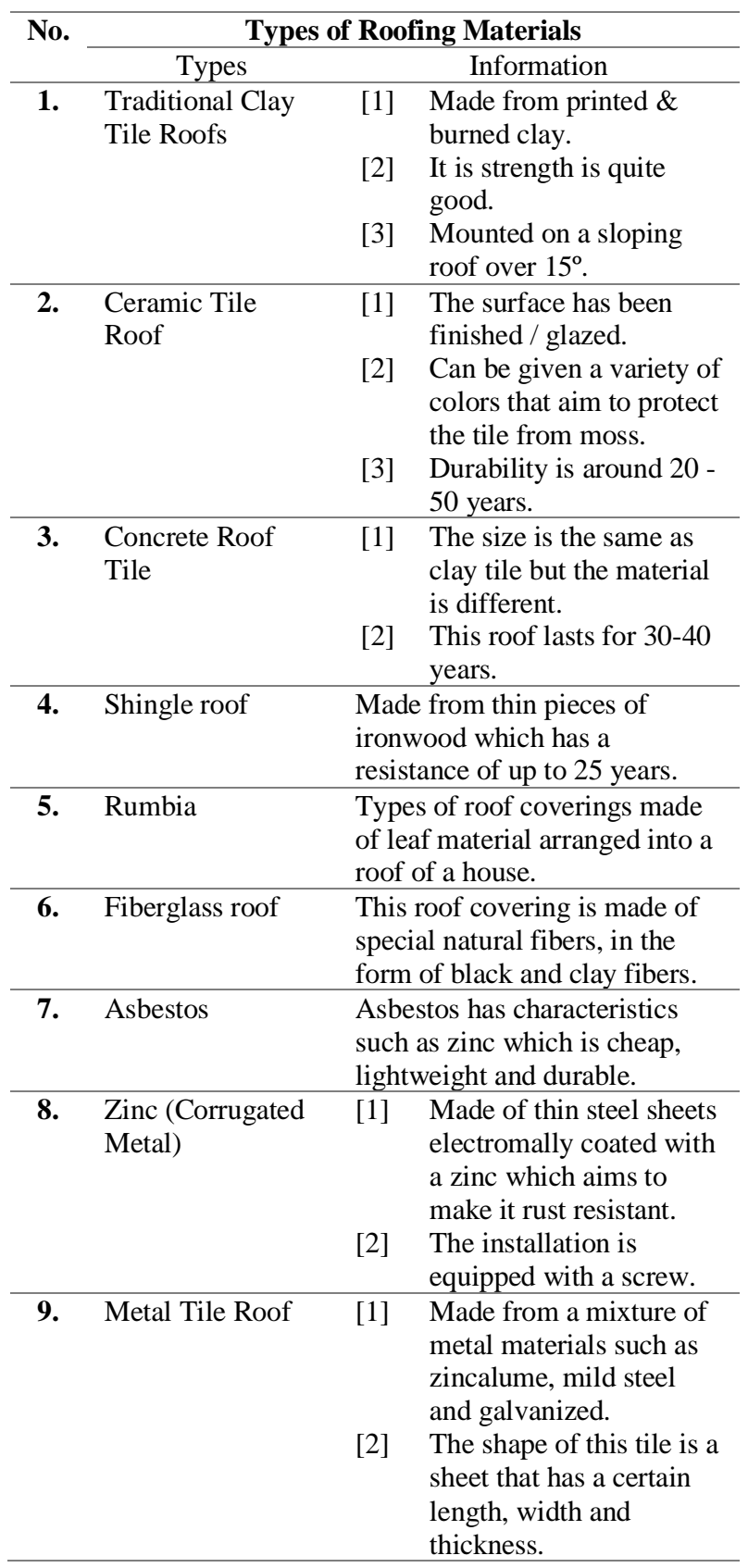




\begin{tabular}{cll}
\hline 10. & Aluminum & $\begin{array}{l}\text { Materials that have ease and } \\
\text { flexibility because they can be } \\
\text { opened and closed easily. }\end{array}$ \\
\hline 11. & $\begin{array}{l}\text { Polycarbonate } \\
\text { Roof }\end{array}$ & $\begin{array}{l}\text { This roof is in the form of large } \\
\text { sheets which are installed } \\
\text { without a connection. }\end{array}$ \\
\hline 12. & $\begin{array}{l}\text { PVC ( Polyvinyl } \\
\text { Chloride ) }\end{array}$ & $\begin{array}{l}\text { This roof covering material is } \\
\text { widely used and its position } \\
\text { between fiberglass and } \\
\text { polycarbonate and this material } \\
\text { is more durable and } \\
\text { inexpensive. }\end{array}$ \\
\hline 13. & Asphalt Tile & $\begin{array}{l}\text { Are transparent and are made } \\
\text { from a mixture of bitumen } \\
\text { sheets and chemicals. }\end{array}$ \\
& &
\end{tabular}

Source: (Jayasinghe)

\subsection{Material Plafond}

Ceiling covering material is divided into four types, namely plywood, fiber cement, cardboard casts, and wooden boards. Plywood (plywood) is a ceiling material that can be formed according to the size and shape of the planned ceiling construction [9].

\subsection{Material Floor Covering}

Floor covering is a piece of building equipment with mechanical use that causes material wear, consisting of several types, including wood boards, parquet, ceramic floors. Wood plank flooring is the simplest floor construction planks that are directly mounted and nailed on a sloop or attic beam. The board size used is a minimum thickness of $20 \mathrm{~mm}$, width 90-140 $\mathrm{mm}$ [9]. Ceramics comes from Greek ceramics, which means a form of clay that has undergone combustion.

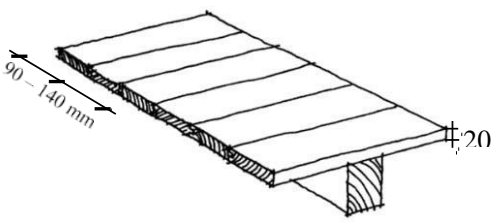

Source: (Heinz Frick)

Figure 9: Hardwood Flooring

\section{Results and Discussions}

\subsection{Mass Arrangement of Contoured Land}

The order of the masses in regional development greatly affects the outer space that will be generated. Therefore, the mass of the building that is arranged without considering the formed outer space will result in an unclear path. The Salse area is located in a contoured area. Therefore, the mass order of this area is arranged according to the existing contour by considering the view for the function of the building with a diagonal spread.

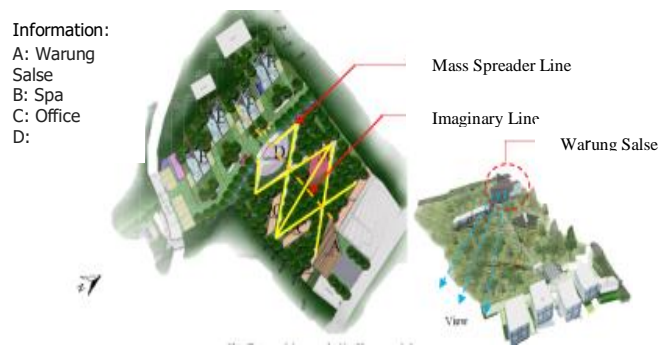

Source: (Author, 2020)

Figure 10: Mass Arrangement at Salse Area Site

\subsection{Mass Forms of the Salse Stalls Building}

Warung salse refers to 3 theories, namely position, orientation, and visual inertia [2] with a square base shape which is then processed by the presence of substrates and additives that form an orientation that produces visual inertia as if the building was rotated. Warung Salse has an attraction on the roof.

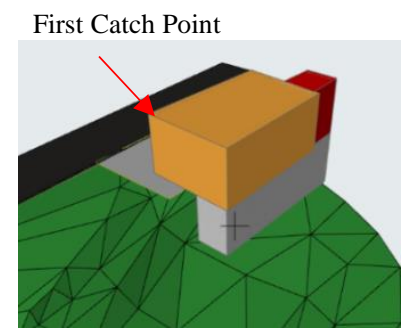

Source: (Author, 2020)

Figure 11: Initial Form of Warung Salse 
The mass position of the Warung Salse building facing the main road gives the impression of a form of energy, as shown in Figure 11.

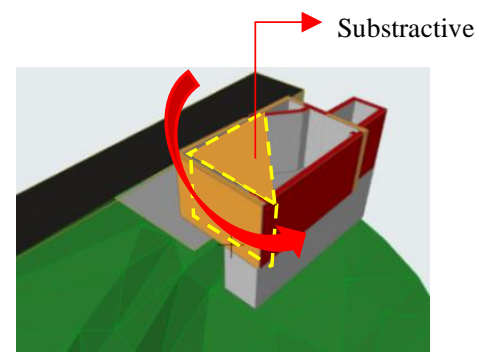

Source: (Author, 2020)

Figure 12: Forms of Salse Substrate that is Extracted

In figure 12, the mass form is processed by subtractive and produces orientation or the main visual point on the building.

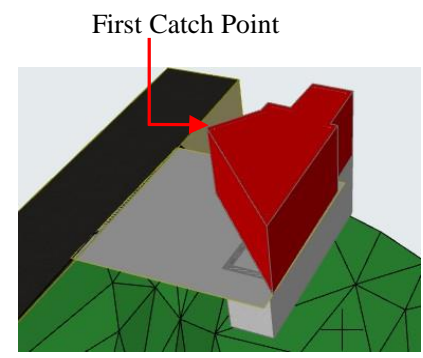

Source: (Author, 2020)

Figure 13: Final Form of Warung Salse

The final shape of the building has a main focal point on the front corner, which can be seen in Figure 13.

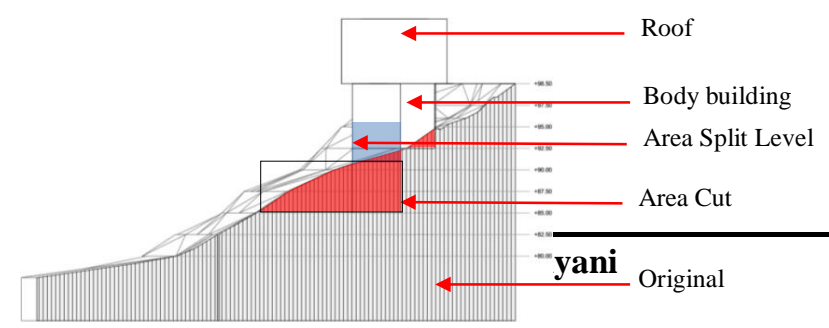

Source: (Author, 2020)

Figure 14: Section of Warung Salse

Figure 14 shows the cut shape of the mass of the Warung Salse building on contoured land.

\subsection{Building Roof Froms}

The shape of the roof of the building adapts to the shape of the space in the building. For example, the roof of Warung Salse follows the mass of the building with a gable roof with two support points [2], as shown in Figure 15.

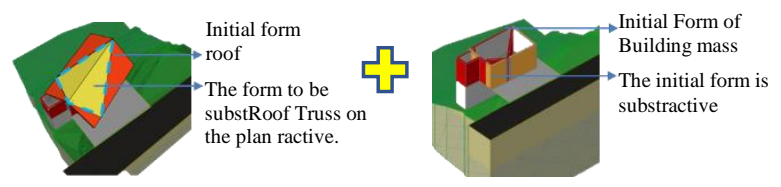

Source: (Author, 2020)

Figure 15: Processing of roof forms

The roof of Warung Salah starts from a saddle roof, then the shape of the roof is subtractive following the mountain view, the better the view of the roof shape is getting smaller. To harmonize the shape of the roof and the mass of the building, the shape of the building mass is subtractive to follow the shape of the roof.

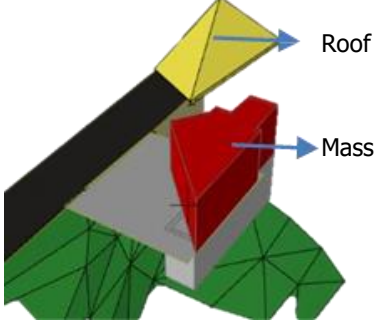

Source : (Author, 2020) 
Figure 16: the final form of the mass and roof

The shape of Warung Salse's roof was developed into the shape of a kite, which is the main catching point of the building as shown in figure 16. The roof is made to reach the ground at the front which attracts the attention of the visitors and the form of the rear roof which is devoted to displaying the main view of the building, then made not cover the façade

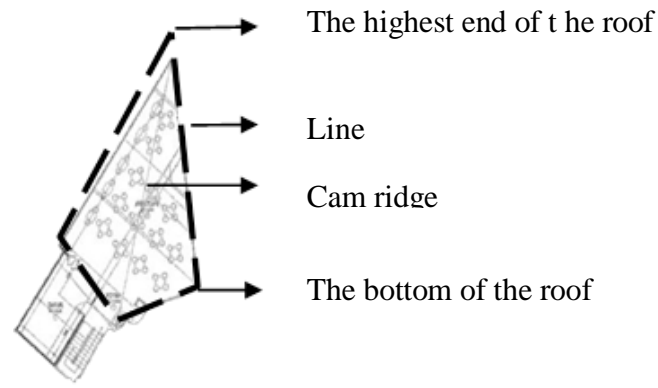

Source: (Author, 2020)

Figure 17: The Gable Roof model developed was seen from the plan

\subsection{Adjusment of Structure to the Form of Building in Countoured Land}

The choice of structure is related to the architectural model so that it has a harmony between structure and architecture. Warung Salse uses two types of structures, namely steel structures and concrete structures. Steel structures are used on the upper floors of buildings because roof structures are more easily formed using steel structures. The shape of the roof that reaches the ground is used upper structure steel material in contoured land, which is efficient. Concrete structures are used on the lower floors to support the top floor structures that are in direct contact with the ground because the structure has durability, corrosion resistance and can be the primary structure for building support.

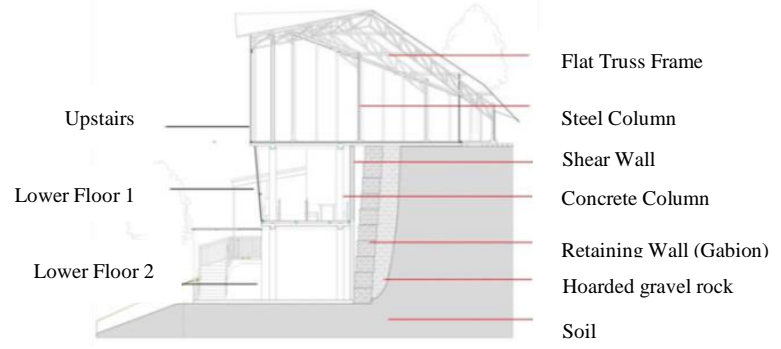

Source : (Author, 2020)

Figure 18: Section of Warung Salse

\subsection{Column}

Warung Salse uses two types of columns, namely concrete columns and steel columns [5]. Downstairs 1 and downstairs, two primary columns use concrete columns, with a size of $30 \times 30 \mathrm{~cm}$, for the canopy roof support on the lower floor 2, using practical steel columns with joints using plates. This column is connected directly to the hollow frame in the canopy by welding. In contrast, the column uses mild steel in the upper floor dining area to reduce the burden on the ground floor one and ground floor 2, which is connected to the concrete column using steel plates bolted and bolted. Finally, on the top floor, the column is placed on the main part of the roof truss.

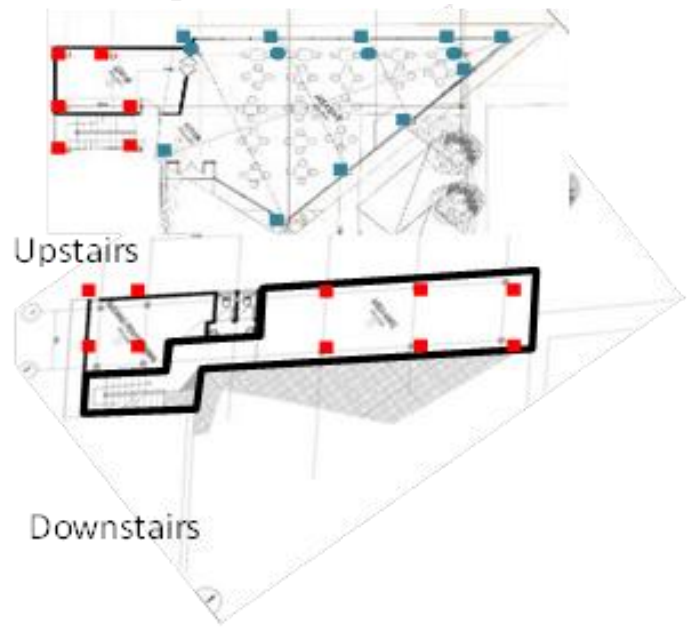

Source : (Author, 2020)

Figure 20: Placement of Columns on the Plan 


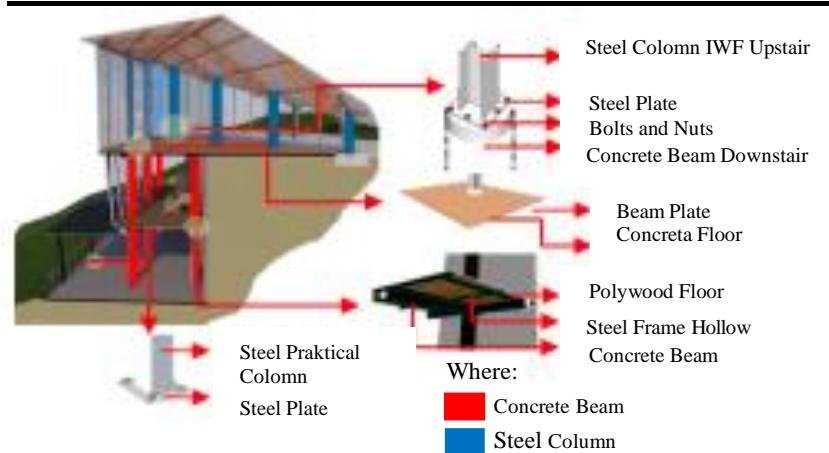

Source : (Author, 2020)

Figure 21: Column Placement in 3D

\subsection{Beam}

Warung Salse uses two types of blocks, namely concrete beams and steel beams [5]. Concrete beams are used to support concrete floors with ceramic finishes, and steel beams are used to support wooden floors.

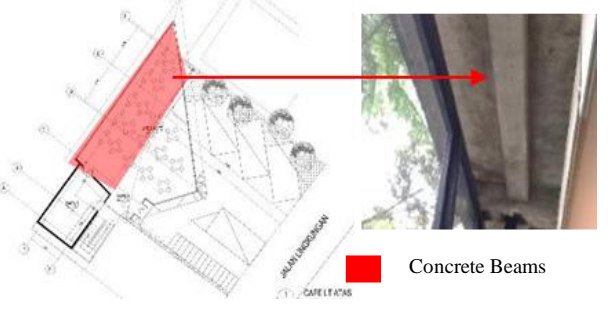

Source : (Author, 2020)

Figure 22: Placement of concrete beams on upper floor

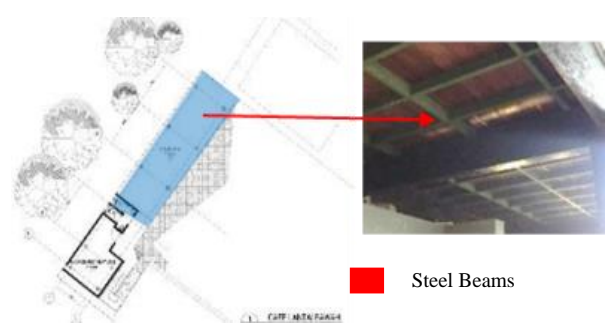

Source : (Author, 2020)

Figure 23: Placement of steel beams in the ground floor

\subsection{Roof Truss}

Warung Salse uses a portal beam structure with a flat truss roof frame [5] so that the roof frame rests on the steel column. The roof frame only $\cdots$ gording because the roof cover uses sheet ll zinc.

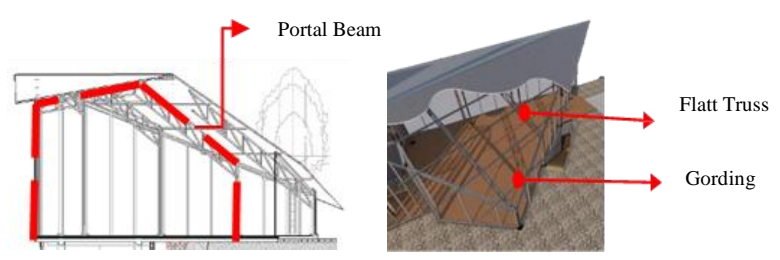

Source : (Author, 2020)

Figure 24: Roof Truss in 3D

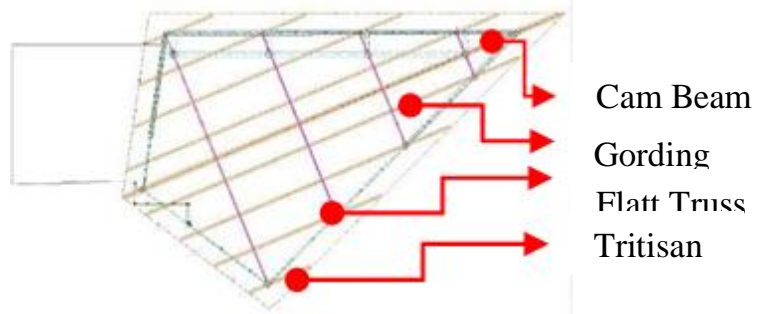

Source : (Author, 2020)

Figure 25: Roof Truss on the Plan

\subsection{Structure Against Contoured Land}

The main structure on contoured land is the retaining wall. The primary task of a retaining wall structure is to accommodate and transmit pressure soil. Selection of type and construction retaining wall depending on the local circumstances (mainly related to place jobs and landslide hazards). In the Warung Salse building, the determination and selection of retaining walls are significant and influential because of its location on a slope or contoured land, with soil instability. The retaining wall of gabions is preferable because the material used is easy to obtain, using a cut of natural stone material [8].

The use of gabions was chosen to hold the soil in contoured areas and prevent erosion in the Salse region due to the instability of groundwater. Gabions are used on floors $2 \& 3$ of buildings because the soil has been cut and 
filled, making one side of the building buried under the ground.

There is space between the masonry wall and the gabion because it prevents groundwater seepage into the building.

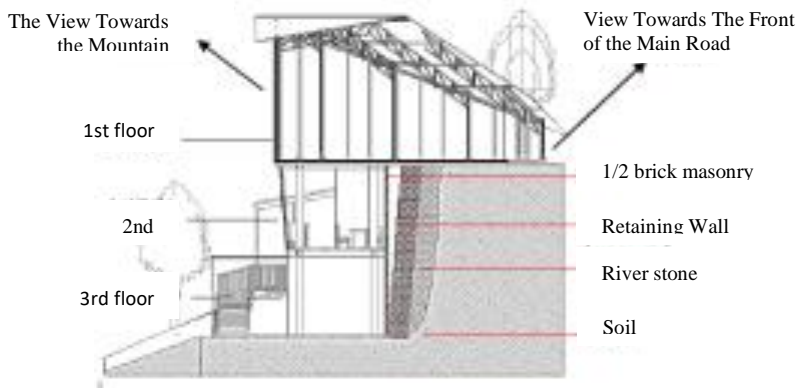

Source : (Author, 2020)

Figure 26: Structure Pieces

\subsection{Materials}

The choice of Warung Salse material is based on the contoured land conditions and climate of the region. The choice of roofing material uses zinc metal waves. This material was chosen because it is lightweight and easy to install. After all, it is in the form of corrugated metal zinc sheets [9]. Existing materials in this building include steel used in the main column supporting the roof, practical columns, cantilever support, glass frames for building walls, and beams to support the lower floor 1 . Concrete is used for floor plates on parts that touch the ground directly, such as on the upper floor with ceramic floor finishing [10] and the lower floor 2 with acian finishing. Wooden plank floors are used on the lower floor one because it is located in an outdoor area that is not in direct contact with the ground.

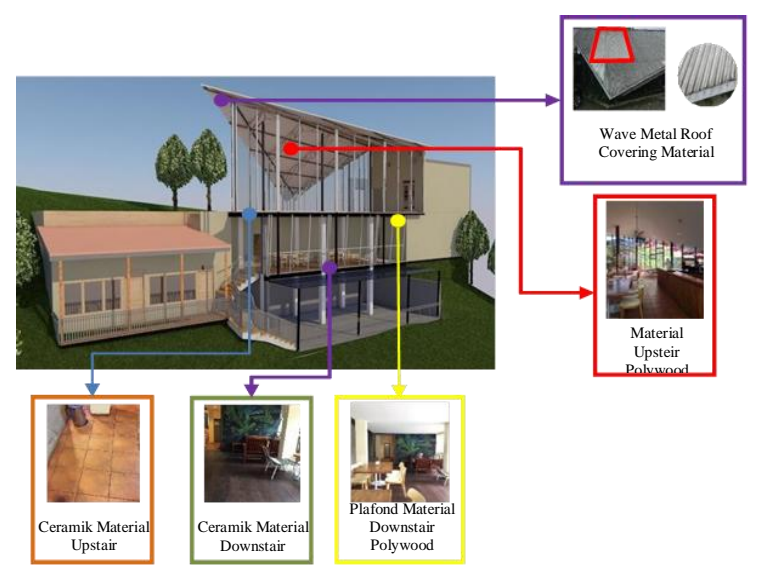

Source : (Author, 2020)

Figure 27: 3D Material Usage

\section{Conclusion}

Based on the results of research on a structural design that adapts to the shape of the building mass on contoured land at Warung Salse, as presented in the above discussion, the following conclusions can be drawn:

From an architectural perspective, [1]The mass arrangement in the Salse area requires special processing because it is located in contoured land using the cut and fill and split level methods that affect the building mass's shape.

[2]The shape of the roof of the building is in harmony with the shape of the mass of the building so that inner space is formed that is in harmony with the roof.

[3]At Warung Salse, the selected materials are adapted to the tropical climate and building concept. The materials applied are light and resemble natural materials, such as steel columns which are finished using colored paint colors such as wood, ceramic colored floors such as soil, and natural wood planks for floor coverings.

In terms of structure,

[1]The structure of the retaining wall used to minimize erosion due to the instability of groundwater on contoured land in the false area 
is a gabion type because the retaining wall material is easy to obtain (natural stone) and can be seen from the slope of the land, which reaches 40 degrees.

[2] The building structure used at Warung

Salse uses a flat truss roof frame integrated into the steel column to form a portal beam structure.

[3] To reduce the building load at Warung

Salse uses two types of structures: the steel structure on the top floor because steel is a structure that is easily formed, efficient in carrying out work, and supports the mass model on contoured land, while the concrete structure is used on the 1st and lower floors. Lower floors 2 , because the concrete is resistant to corrosion, has a balance in continuing the load of the building.

The benefits obtained from this structural model can be seen from the space in the building because it is multifunctional as a roof and wall covering so that the structure and mass shape of the building is formed in harmony with the roof.

The external environment that must be preserved makes the choice of Warung Salse's material based on the contours of the soil and climatic conditions of the area-for example, choosing a roofing material that uses zinc was chosen because it is light and easy to install because it is in sheet form. The materials in this building include mild steel, concrete, ceramics, and wood. The choice of ceramic material and wooden floor coverings also affects the space in the building and adjusts to the climate in the area. Wood material was chosen because it is used in semi-outdoor areas with steel frames to avoid termites, and ceramic materials are used because the upper floor area is in direct contact with the ground surface.

\section{References}

[1] Adisasmita, Rahardjo. Regional Development and Spatial Planning. Graha Science; 2010.

[2] Ching, D.k. Spatial Form and Order. Erlangga; 2007.
[3] Frick, Heinz. Build and inhabit houses on slopes. Yogyakarta: Kanisius; 2003.

[4] Hardiyatmo. Land Mechanics. ebook; 2014.

[5] Idham, Cholis Noor. Designing Low-rise Buildings. Yogyakarta, Graha Science.

[6] Frick, Heinz. Building Construction Science. Yogyakarta; Kanisius; 2007.

[7]Dishoung, Burl Edward. Essential Structural Technology for Construction and Architecture: 2010

[8] Frick, Heinz. Building Structure Basics of Construction in Architecture. Yogyakarta: Kanisius.

[9] Jayasinghe, M.T.R, et al. Roof Orientation,

Roofing Materials. And Roof Surface Color. Their Influence On Indoor Thermal Comfort In Warm Humid Climates.

[10] Frick, Heinz. Wooden Building Construction. Ebook. 